\title{
PROCESS CONTROL ON REMOVAL OF IRON FROM INDUSTRIAL WASTEWATER USING ELECTROCHEMICAL TECHNIQUE
}

\author{
Rasha Ahmed Hefny ${ }^{1 *}$, Mohamed Hanafy Mahmoud ${ }^{2}$, Ali Mohamed Basstawesy ${ }^{1}$, Omar El-Farouk $^{2}$ \\ Abdel-Salam ${ }^{2}$, and Nasser Ali Barakat ${ }^{1,}$ \\ ${ }^{1}$ Chemical Engineering Department, Faculty of Engineering, Minia University, Egypt. \\ ${ }^{2}$ Chemical Engineering Department, Faculty of Engineering, Cairo University, Egypt. \\ "Corresponding Author E-mail: rasha_hefny@yahoo.com
}

\begin{abstract}
The design of control systems is very important in industry. In this work process_control of the proposed electrochemical cell was applied. The results of experiments conducted on the electrochemical cell were taken as the operating data. The parameters affected on the removal process were feed flow rate, feed concentration, and current density. The process control was developed to produce an environmentally acceptable output of iron concentration. The dynamic model and the results of the calculated open and closed loops response curves with the suggested control mode of the electrochemical cell are presented using Matlab.
\end{abstract}

Keywords: Dynamic systems, $P$ controller, Feedback control system, Iron removal.

\section{INTRODUCTION}

Discharging large amounts of heavy metal-polluted wastewater is the main problem facing many industries. Cadmium, copper, mercury, lead, zinc and iron are the heavy metals of greatest concern in wastewater treatment [1]. Heavy metal ions are not biodegradable and have a tendency to accumulate in living beings, and many of them are known to be toxic [2]. Therefore, heavy metals must be removed from wastewater to protect humans and the environment [3]. Iron ions pollutants are presented in industrial wastewaters due to the corrosion of equipment and pipelines in industrial plants. So the removal of iron ions from industrial wastewaters are very important to satisfy environmental restrictions [1]. Different techniques are used to remove heavy metal ions such as chemical precipitation, membrane ion

Received:5 November, 2019, Accepted: 3 January, 2020 exchange, adsorption, electrochemical treatment, photocatalysis and nanotechnology [4].

Among the heavy metal removal processes, electrochemical treatment has attracted the greatest attention because it is a safe approach for the long-term clean-up of metal- bearing aqueous wastes [5, 6]. In electrochemical techniques, metal ions are precipitated on a cathode surface and can be recovered in their elemental state. In addition, the active ions can be indirectly precipitated by adequate electrochemical oxidation of the active ions to form waterinsoluble salts. Current density and flow rate are the most important parameters affected metal ion removal from wastewater.

To achieve an industrially acceptable iron removal unit, devices should be equipped with a proper control system and a controller should be designed. [7]. A control system consists of different components 
should be developed to make a relationship between the input and the output variables for each component of a control system [8]. MATLAB, the language of technical computation developed by math works, is powerful modelling software. [9, 10].

In this study, flow-by porous graphite electrodes electrochemical cell was used to remove iron from simulated industrial wastewater. The obtained experimental data were used to design a process control loop using Matlab to modify the current density in response to variations in the flow rate and initial iron concentration.

\section{MATERIALS AND EXPERIMENTAL}

As shown in Figure (1), the cell consisted of two co-axial cylinders fixed to end flanges. The outer cylinder is $15 \mathrm{~cm}$ diameter and $18 \mathrm{~cm}$ height. The inner screen cylinder (mesh 5) with $10 \mathrm{~cm}$ diameter was enclosed in a polyamide membrane and was used as the anode compartment. The cathode was the annular space between the two cylinders. Cathode and anode compartments were filled with graphite granules. The feed solution entered to the cell using a dosing pump to control the feed flow rate. A DC power supply was used with a digital multimeter to measure the potential and current. The iron concentration was measured by using a spectrometer. Simulated ironpolluted solutions with different iron concentrations were prepared by dissolving $\mathrm{FeSO}_{4} .7 \mathrm{H}_{2} \mathrm{O}$ in distilled water.

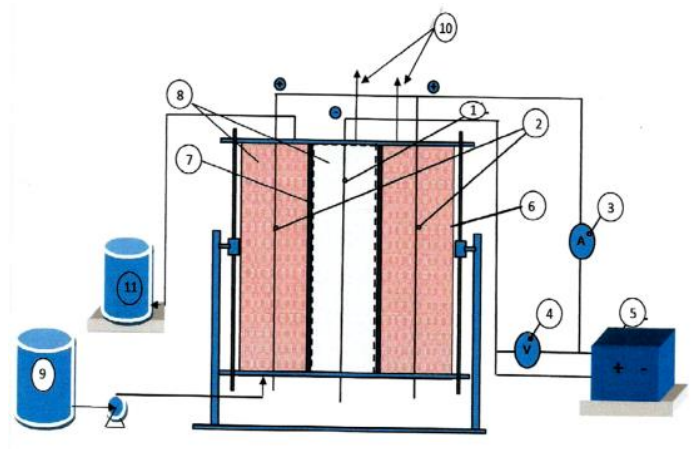

Fig.1. Schematic of the experimental setup: 1) anode current collector; 2) cathode current collector; 3) ammeter; 4) voltmeter; 5) DC power supply; 6) outer cylinder; 7) inner cylinder; 8) graphite; 9) iron solution tank; 10) gas vents; 11) treated water tank; 12) dosing pump.

\section{DYNAMIC MODEL AND BLOCK DIAGRAM}

\subsection{Model assumption}

The concentration of iron in the cathode bed was calculated as follow:-

$$
\mathrm{C}=\left(\mathrm{C}_{\mathrm{o}}+\mathrm{C}_{\mathrm{i}}\right) / 2
$$

where:

$\mathrm{C}$ is the concentration of iron in the anode bed, $\mathrm{g} / \mathrm{l}$.

$\mathrm{C}_{\mathrm{o}}$ is the outlet concentration of iron, $\mathrm{g} / \mathrm{l}$.

$\mathrm{C}_{\mathrm{i}}$ is the inlet concentration of iron, $\mathrm{g} / \mathrm{l}$.

\subsection{Unsteady-state material balance}

The unsteady material equation is as follow:

(VE) $\mathrm{dC} / \mathrm{dt}=\mathrm{F} \times \mathrm{C}_{\mathrm{i}}-\left(\mathrm{F} \times \mathrm{C}_{\mathrm{o}}+\mathrm{I} \times \mathrm{e} / 96500\right)$

Where: (VE) $\mathrm{dC} / \mathrm{dt}$ is the mass of iron accumulated, $\mathrm{F} \times \mathrm{C}_{\mathrm{o}}$ is the mass rate of iron out $(\mathrm{g} / \mathrm{s})$, and Ixe $/ 96500$ is the mass of iron removed. $\mathrm{F}=$ feed flow rate $(1 / \mathrm{s}), \mathrm{V}=$ volume of the electrode (1), $\mathrm{C}=$ porosity of the graphite bed in the electrode, e = equivalent weight of iron (II), and $\mathrm{I}=$ applied current (A) and $\mathrm{F} \times \mathrm{Ci}$ is the mass rate of iron in $(\mathrm{g} / \mathrm{s})$. After linearization and applying the Laplace transformation technique, the following equation was obtained:

$$
\begin{aligned}
& \mathrm{k}_{1} \times \mathrm{F}(\mathrm{s})+(1-\tau \mathrm{S}) \times \mathrm{C}_{\mathrm{i}}(\mathrm{s})+\mathrm{k}_{2} \times \mathrm{I}(\mathrm{s})= \\
& (1+\tau \mathrm{S}) \times \mathrm{C}_{\mathrm{o}}(\mathrm{s}) \\
& \text { where: } \\
& \mathrm{k}_{1} \quad=\mathrm{C}_{\mathrm{i}}(\mathrm{o})-\mathrm{C}_{\mathrm{o}}(\mathrm{o}) / \mathrm{F}(\mathrm{o}) \\
& \mathrm{k}_{2}=-2.9 \times 10^{-4} / \mathrm{F}(\mathrm{o}) \\
& \tau=0.09152 / \mathrm{F}(\mathrm{o})
\end{aligned}
$$

From the results of experiments conducted on the electrochemical cell, the average steady state gains $\left(\mathrm{k}_{1}\right.$ and $\left.\mathrm{k}_{2}\right)$ and time constant $(\tau)$ of the cell are as follows: 
$\mathrm{k}_{1}=164.16 \mathrm{~g} \mathrm{~s} / 1^{2}, \mathrm{k}_{2}=-0.42 \mathrm{~g} / \mathrm{A} . \mathrm{s}$ and $\tau=380 \mathrm{~s}$.

\subsection{Open loop calculations}

The dynamic behaviour of the outlet concentration of iron for the input disturbances of the cell (feed flow rate, inlet concentration of iron and applied current density) was developed. The open loop calculations were carried out at initial concentration of $200 \mathrm{ppm}$, feed rate 0.56 $\mathrm{ml} / \mathrm{s}$ and current density $\quad 0.49 \mathrm{~mA} / \mathrm{cm}^{2}$.

The response of the outlet concentration to step of feed rate by $+12 \%$ is shown in Figure (2) and to step of inlet concentration by $+10 \%$ is shown in Figure (3)

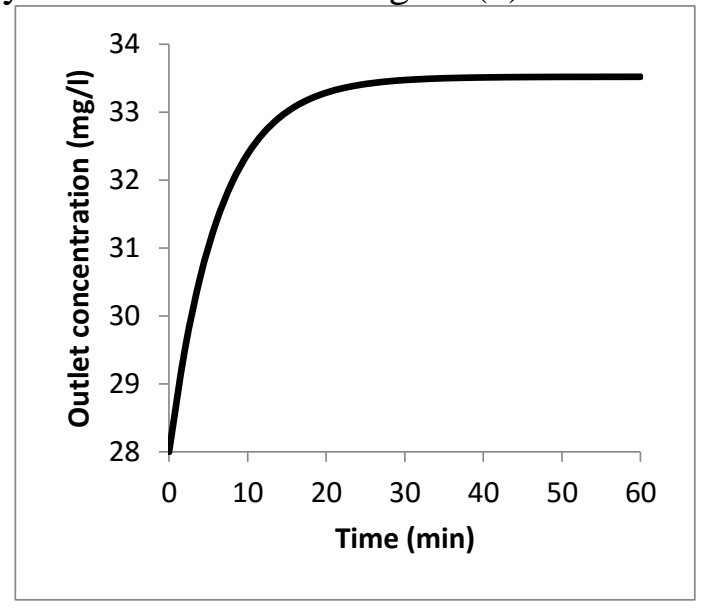

Fig.2. Open loop response curve of outlet concentration to feed rate step change.

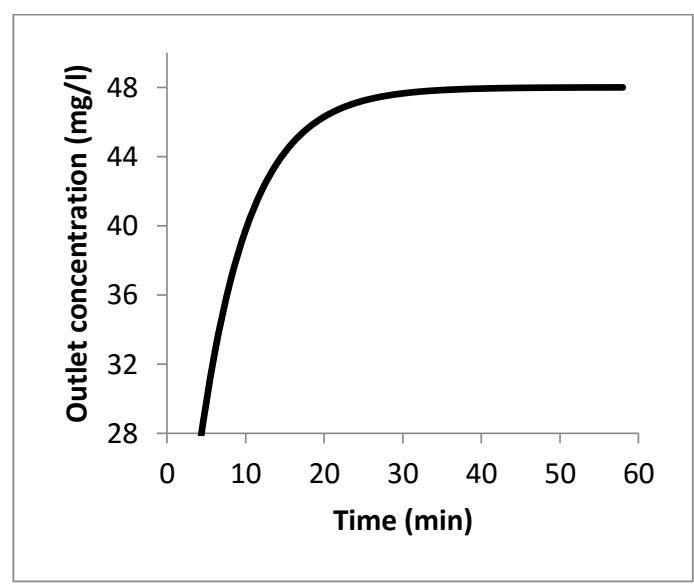

Fig. 3. Open loop response curve of outlet concentration to inlet concentration step change.
Figure (4) shows the effect of step change of applied current by $+20 \%$ on the outlet concentration of iron.

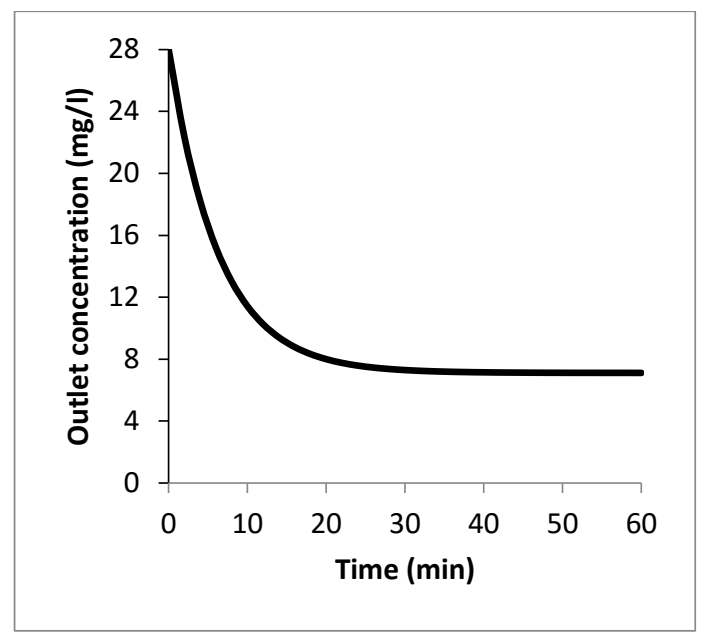

Fig.4. Open loop response curve of outlet concentration to applied current step change.

\section{CLOSED LOOP CALCULATIONS}

The block diagram of a feedback control system representing the suggested control system is given in Figure (5). The iron concentration is measured by using a spectrophotometer. The controller compares the measured value with a set point. The controller output signal is applied in the cell using a voltage amplifier as a final control element.

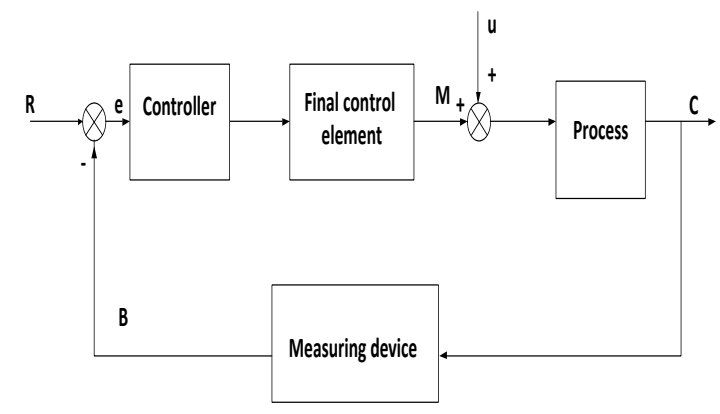

Fig. 5. Block diagram of a feedback control system.

Transfer function of automatic sampler and spectrophotometer is (T.F $=\mathrm{k} \mathrm{e}^{-\tau \mathrm{m}} \mathrm{S}$ ) where: $\mathrm{k}=1 \mathrm{~V} / \mathrm{g} / \mathrm{l}$ and $\tau_{\mathrm{m}}=300 \mathrm{~s}$, and transfer function of inverting amplifier is (T.F $=\mathrm{k}_{\mathrm{a}} /$ $\left(1+\tau_{\mathrm{a}}\right)$ ) where: $\mathrm{k}_{\mathrm{a}}=-50 \mathrm{~V} / \mathrm{mV}$ and $\tau_{\mathrm{a}}=1 \mathrm{~s}$ [8]. 


\subsection{Calculation of controller settings}

Ziegler-Nichols closed-loop method was used to calculate the tuning parameter of controller [11]. The ultimate gain $\left(\mathrm{k}_{\mathrm{u}}\right)$ and ultimate period $\left(\mathrm{P}_{\mathrm{u}}\right)$ were calculated and found to be $\mathrm{k}_{\mathrm{u}}=62 \mathrm{mV} / \mathrm{V}$ and $\mathrm{P}_{\mathrm{u}}=24 \mathrm{~s}$. Based on this method, the tuning parameter for the proportional $(\mathrm{P})$ controller is $\mathrm{k}_{\mathrm{c}}=31$ $\mathrm{mV} / \mathrm{V}$.

\subsection{Closed Loop Response Curves for}

\section{Outlet Concentration}

MATLAB was used in modelling of feedback closed loop using $\mathrm{P}$ controller for step changes of different disturbances under regulator operation and in tuning of the $\mathrm{P}$ controller's parameter to insure system stability [12]. Then closed loop responses for step changes of different disturbances under regulator operation are presented.

As shown in Figures (6) and (7) a proportional $(\mathrm{P})$ controller can be used to control this process, because it has a good speed of response and acceptable offset value [13].

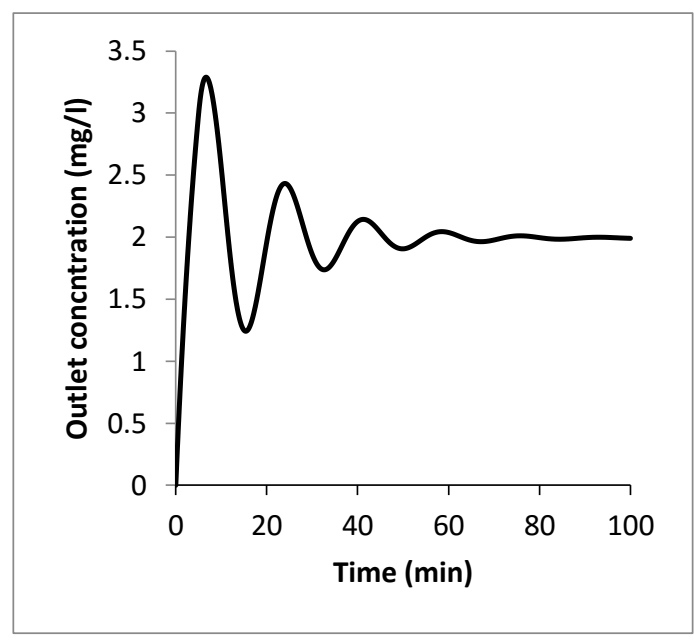

Fig. 6. Closed loop response curve of outlet concentration to step change of feed rate, by $12 \%$ using P controller.

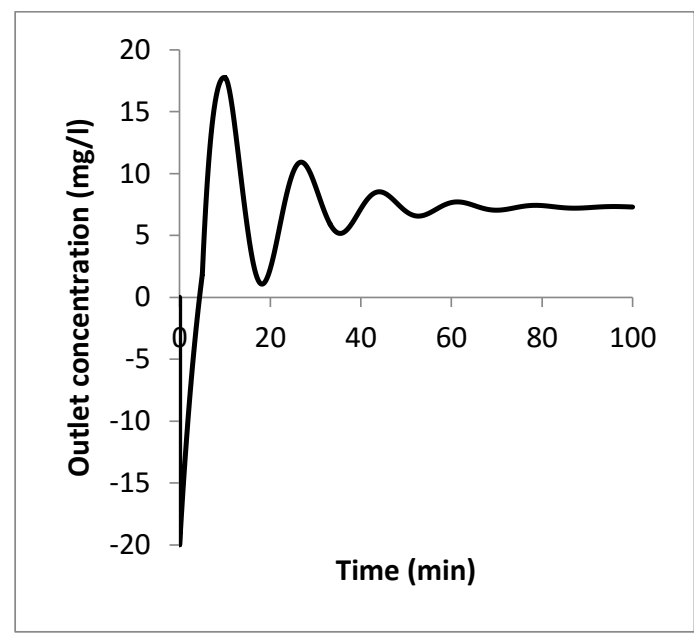

Fig.7. Closed loop response curve of outlet concentration to step increase of inlet concentration, by $10 \%$ using $\mathrm{P}$ controller.

\section{CONCLUSIONS}

Process control system of the proposed electrochemical cell was developed. The system was based on varying the applied current density with changing iron concentrations in the feed to produce an acceptable output concentration. A feedback control system for the electrochemical cell using a Proportional (P) controller was suggested since the process has a good speed of response and acceptable offset value.

\section{REFERENCES}

[1] Gherasim, C.-V. and P. Mikulášek, Influence of operating variables on the removal of heavy metal ions from aqueous solutions by nanofiltration. Desalination, 343, p. 67-74, 2014.

[2] Hong-gui,D., et al., Comprehensive assessment model on heavy metal pollution in soil. Int $\mathbf{J}$ Electrochem Sci, 7(6), p. 5286-5296, 2012.

[3] Fu, F. and Q. Wang, Removal of heavy metal ions from wastewaters: a review. Journal of environmental management, 92(3), p. 407-418, 2011.

[4] Azimi, A., et al., Removal of heavy metals from industrial wastewaters: a review. ChemBioEng Reviews, 4(1), p. 37-59, 2017.

[5] Alajami, M., et al., Influence of bimetallic nanoparticles composition 
and synthesis temperature on the electrocatalytic activity of NiMnincorporated carbon nanofibers toward urea oxidation. International Journal of Hydrogen Energy, 43(11), p. 55615575, 2018.

[6] Yousef, A., et al., Fabrication of Electrical Conductive NiCu-Carbon Nanocomposite for Direct Ethanol Fuel Cells. Int. J. Electrochem. Sci, 10, p. 7025-7032, 2015.

[7] Stephanopoulos, G., Chemical process control: an introduction to theory and practice, 1984.

[8] Vyas, R., Process Instrumentation and Control. Dennett and Co, p. 99-105.

[9] Maddali, R.K., Modeling ordinary differential equations in MATLAB Simulink. Indian Journal of Computer Science and Engineering, 3(3), p. 40610, 2012.
[10] Yeo, Y.K., Chemical Engineering Computation with MATLAB ${ }^{\circledR}, \quad$ CRC Press, 2017.

[11] Bequette, B.W., Process control: modeling, design, and simulation, Prentice Hall Professional, 2003.

[12] Oza, R., et al., Application of MATLAB in Process Control: Case Study for First Order Reaction in a CSTR. Nirma University Journal of Engineering and Technology (NUJET), 1(1), p. 45-49, 2000.

[13] Chau, P.C., Process control: a first course with MATLAB, Cambridge University Press, 2002. 
Vol. 40, No. 1. January 2021

التحكم فى ازالة الحديد من مياه الصرف الصناعى بالطريقة الكيميائية

الملخص :

تصميم أنظمة التحكم مهم جدا في الصناعة. في هذا العمل تم تطبيق التحكم الالي علي الخلية الكهروكيميائية المقترحة. أخذت نتائج التجارب التي أجريت على الخلية الكهروكيميائية كبيانات لتشغيل نموذج التحكم الالي. العوامل التي أثرت في عملية الإزالة هي معدل سريان سائل التغذية ، وتركيز الحديد في سائل التغذية ، وكثافة التيار الكهربي. تم تطبيق التحكم في العملية لإنتاج ناتج مقبول بيئًا لتركيز الحديد. تم عرض النموذج الديناميكي ونتائج منحنيات الاستجابة بدون استخدام التحكم و مع وضع التحكم المقترح للخلية الكهروكيميائية باستخدام Simulink. 